\title{
THE EFFECT OF CORPORATE GOVERNANCE MECHANISMS ON THE VALUATION OF COMPREHENSIVE INCOME REPORTING IN NIGERIA
}

\author{
ALIYU BABA USMAN \\ Department of Accounting, Ibrahim Badamasi Babangida University, \\ New Bussa Campus, Nigeria \\ NOOR AFZA AMRAN \\ HASNAH SHAARI \\ Tunku Puteri Intan Safinaz (TISSA-UUM), \\ Universiti Utara Malaysia, 06010 UUM Sintok, Kedah, Malaysia
}

\begin{abstract}
This study investigates the influence of corporate governance mechanisms on the valuation of other comprehensive income in Nigeria. The sample of this study consists of 327 firm-year observations comprising of 117 firms listed on the Nigerian Stock Exchange for the period of 2010 to 2014. The findings reveal that there is a positive influence of corporate governance mechanism on the investors' pricing of other comprehensive income. Findings show that for firms with weak governance mechanisms, other comprehensive income is value relevant, but is more significantly priced for strong governance firms. This study finds a similar result when other comprehensive income interact with individual elements of corporate governance factor. Therefore, corporate governance mitigates reliability concerns associated with fair value earnings, agency cost will be minimised and investors are more likely to view other comprehensive income as more value relevant. It is therefore recommended that reporting entities should pursue best corporate governance practices in order to enhance investors' confidence in the reliability of other comprehensive income.
\end{abstract}

Keywords: Corporate governance, Other comprehensive income, Value relevance.

\section{Introduction}

An old and unresolved challenge facing standardsetters and users of accounting information centres is the choice of a more appropriate method of assessing the periodic financial position and performance (Kanagaretnam, Mathieu, \& Shehata, 2009). The proponents of the inclusive approach contend that all changes in the value of assets and liabilities measured at the market value are derived from the income statement. Such an approach of measuring periodic performance is considered more appropriate because it explicitly shows all changes in the value of assets and liabilities at the beginning and at the end of the financial period (Firescu, 2015). Thus, by presenting all cash flow changes resulting for both fair value changes in balance sheet items and cash flows from operating performance, users of financial statements can easily distinguish between value creation and value distribution (Chambers, Linsmeier, Shakespeare, \& Sougiannis, 2007; Kanagaretnam et al., 2009; Mechelli \& Cimini, 2014; Firescu, 2015). This is contrary to the current operating performance approach where temporary changes (dirty surplus flows) arising from non-core operations bypass the income statement and are reported directly in the balance sheet under the owners' equity section (Kanagaretnam et al., 2009; Lee \& Park, 2013). To justify the desirability of 
the all inclusive income approach, such as Comprehensive Income (CI), it has been argued that reporting dirty surplus flows directly to the balance sheet "may encourage management to opportunistically manage earnings. This may cause misleading inferences to be drawn by the users of accounting information" (Kanagaretnam et al., 2009). Therefore, considering the comprehensiveness of the all inclusive approach to measure financial performance, the CI-type statement displays all relevant components of income (Hirst \& Hopkins, 1998; Kanagaretnam et al., 2009; Lee \& Park, 2013; Firescu, 2015).

Seemingly, these anomalies are often curtailed through effective corporate governance (CG) practices which can deter unethical behaviour (Bartov et al., 2007; Song et al., 2010; Lee \& Park, 2013). Corporate monitoring curtails opportunistic tendencies, hence enhancing the reliability and integrity of the financial reporting process (Song et al., 2010; Lee \& Park, 2013). Thus, in valuing $\mathrm{CI}$ and $\mathrm{OCI}$, investors may place different weights on these earnings numbers based on the firms' CG mechanisms (Habib \& Azim, 2008; Song et al., 2010; Lopes \& Walker, 2012; Lee \& Park, 2013).

Corporate governance practices in Nigeria have been observed since the last decade with the promulgation of the Corporate Governance Code 2003 (Adegbite, 2012). Due to the ineffectiveness observed in the 2003 governance code in addressing corporate challenges and part of the arrangement for transition to the IFRS, the federal government through the Security and Exchange Commission issued a revised code of corporate governance in 2011 (Adegbite, 2012). Therefore, given these institutional reforms, users are likely to be become more confident in the information they are provided. This study aims to provide empirical evidence as to how CG mechanisms could ameliorate investors' perception of the reliability of other comprehensive income (OCI) in Nigeria. The CG mechanisms proposed in this study are audit committee independence, audit committee financial expertise, frequency of audit committee meetings, audit committee size, effectiveness of internal control system and external auditor's reputation, which can enhance the value relevance of CI and OCI. The contribution of this study is that the findings expand the understanding of the role of corporate governance mechanisms on the reliability of fair value earnings from the Nigerian perspective. Further, the findings show that disclosure relating to IAS 16, IAS 19 and IFRS 7 are value relevant and have a positive influence on the value relevance of OCI items in the Nigerian Stock Exchange (NSE). Lastly, the findings promote benchmarking among companies by setting high best practices in financial reporting and disclosure to enhance market discipline and reduce uncertainties of fair value earnings.

\section{Prior Studies and Hypotheses Development}

\section{Value Relevance of Other Comprehensive Income and Corporate Governance Mechanisms}

The valuation effect of other comprehensive income has been recognised in the extant literature. Such accounting will "provide the opportunity for managers to manage earnings by selectively including realized gains in earnings and selectively excluding unrealized losses from earnings"' (FASB, 1993). This is typically because other comprehensive income includes several "mark-to-market and mark-tomodel" types of adjustments. When the degree of judgment and subjectivity in estimating fair-value estimates is high, it increases the dissenting concern about the reliability of such estimates (Maines \& McDaniel, 2000; Song et al., 2010; Lee \& Park, 2013). Consequently, actual results could differ materially from the estimates, hence creating additional challenges for users and auditors of financial information (Christensen et al., 2012; Lee \& Park, 2013). This agency cost of information asymmetry is proven to be mitigated through effective corporate governance practices and market participants prize the strength of corporate governance in investment analysis (Maines \& Wahlen, 2006; Song et al., 2010; Lee \& Park, 2013).

Because other comprehensive income includes several dirty surplus flows measured using 
different levels of hierarchy information, investors are less likely to have the capacity to verify the reliability of such estimates (Lee \& Park, 2013). Nevertheless, previous evidence documented enhanced quality and reliability of financial information when external auditors were involved in the financial reporting process (Ismail \& Chandler, 2005; Francis \& Wang, 2008; DeFond, 2010; Francis \& Michas, 2013; Lee \& Park, 2013). As such, market participants could place different weights for an accounting number audited by Big 4 and non-Big 4 firms because of the perception that $\mathrm{Big} 4$ firms produce higher quality audits than non-Big 4 firms. These assumptions make the nomenclature of Big 4 an effective corporate governance mechanism for capital market operations (Francis \& Michas, 2013; Lee \& Park, 2013). It is, therefore, arguable that involvement of external auditors could influence the investors' pricing of other comprehensive income in Nigeria.

More so, the audit committee, a vital corporate governance oversight function, may have a disciplining effect on the management's discretion in fair value determination. Several regulatory and legislative reforms such as the Blue Ribbon Committee on Improving the Effectiveness of Corporate Audit Committees (BRC) 1999 and the Sarbanes Oxley-Act 2002 underscore the importance of best practices of audit committees in financial reporting quality. For instance, the proportion of independent non-executive directors to the total number of directors sitting on the boards has been positively associated with the comprehensiveness of financial disclosure (Chen \& Jaggi, 2000) and negatively associated with earnings management (Klein, 2002; Jenkins, 2003) and more reliable reported earnings (Woidtke \& Yeh, 2013). By contrast, Rainsbury et al. (2009) and Suárez et al. (2013) revealed that the proportion of independent directors did not enhance the quality of financial reporting, whilst the study by Abdullah and Ku-Ismail (1999) found that only the influence of a firm's size on audit committee effectiveness was significant.

The frequency of audit committee meetings gives the committee members ample time to review internal control systems and a firm's overall audit process to ensure good financial reporting quality (Barua et al., 2010; Woidtke \& Yeh, 2013). In related studies, the frequency of audit committee meetings was found to be negatively associated with discretionary current accruals (Xie et al., 2003) and more likely lead to updating members on current auditing issues, and members were more diligent in fulfilling their duties (Yasin $\&$ Nelson, 2012). Furthermore, the presence of financial and auditing experts sitting on an audit committee leads to higher quality financial statements. The financial expertise of audit committee members seems to be a fundamental factor in monitoring and forestalling earnings management and financial restatements (Xie et al., 2003; Agrawal \& Chadha, 2005). Davidson et al. (2004), DeFond et al. (2005) and Woidtke and Yeh (2013) observed a positive stock market reaction to good news management forecasts for firms with financial and audit expertise on their audit committee. Experts sitting on these committees are effective at reducing internal control problems and inefficiency in financial reporting (Naiker \& Sharma, 2009; Yasin \& Nelson, 2012).

In the same vein, effective implementation and monitoring of internal control systems can assist in detecting and preventing aggressive financial reporting, hence improving financial reporting quality and integrity (Rezaee, 2004; Kim \& Park, 2009). Firms without material internal weakness problems are less likely to have issues relating to estimation errors, intentional manipulation and biased forecasts by management that affect the quality of reported information (Brown et al., 2014). This is because a sound internal control system allows the internal audit staff to monitor the preparation of the annual report effectively (Rezaee, 2004). Overall, the influence of an auditor's reputation, audit committee characteristics and an internal control system is unequivocally important in addressing the agency cost of information asymmetry. Thus, if the assumption is made that the strength of corporate governance mechanism reduces the level of professional judgment involved in fair value measurement, one might expect enhanced reliability of other comprehensive income. It is therefore hypothesised that: 
$H_{1} \quad$ : The strength of the corporate governance positively influences the reliability of other comprehensive income in the Nigerian capital market.

$\mathrm{H}_{2}$ : The individual element of corporate governance positively influences the reliability of other comprehensive income in the Nigerian capital market.

\section{Research Methodology}

\section{Data}

All data regarding accounting numbers (except for other comprehensive income items) and measures of firm value were collected from the Thomson Reuters Database. Missing information from the database and nonfinancial data were hand-collected from annual reports (Barth \& Clinch, 1998; Cahan et al., 2000). Table 1 presents the breakdown of the sample calculations. Panel A splits the full sample into financial and nonfinancial firms for years 2010 to 2014. The initial total sample includes 945 firm-year observations comprising 260 financial firms and 685 nonfinancial firms. 477 firm-year observations (94 financial and 302 nonfinancial) were excluded due to missing data or because all the three components of other comprehensive income are zero. Because this study used the price model that required share price as a dependent variable and the return model that also required dividends for computing stock returns, an additional 100 firm-year observations (35 financial and 65 nonfinancial) for firms without data on share prices and dividends were excluded. Futhermore, another 19 firm-year observations (35 financial and 65 nonfinancial) were deleted because of the extremely large data that would result in abnormal influence. Thus, the final sample presented in Panel A consists of 349 firm-year observations (123 financial and 226 nonfinancial). Panel $\mathrm{B}$ provides a breakdown of the sub-sectors of the major classifications of financial and nonfinancial firms. Banks, insurance companies and investment and financial services constitute the financial sector. The sample firms in the nonfinancial category are from many industries, with the greatest proportion from consumer goods, industrial goods, services and oil and gas; and agricultural and healthcare firms being the least. Panel B also delineates the number of firms in each industry, which demonstrates that no single industry dominates the sample. Panel $\mathrm{C}$ combines the sample and it is the identical requirement for the formation and disclosure of corporate governance practices for both financial and non-financial firms as stipulated by the CAMA 1990 amended in 2004 and SEC 2011. Second, all firms reporting under the IFRS framework are required to mark-to-market or mark-to-model certain assets and liabilities and to report fair value gains and losses using the fair value hierarchy. Third, compliance with relevant accounting standards relating to OCI is almost homogeneous for financial and nonfinancial firms with respect to IAS 16 and IAS 19. Fourth, given the low frequency of fair value reporting and the rigorousness of analysis, it will be more appropriate to combine the sample (Jones \& Smith, 2011; Mechelli \& Cimini, 2014).

Table 1

Sample Calculation for Firms that Passed the Filtering Process

\begin{tabular}{lccc}
\hline Panel A: Sample Calculation for Years 2010 to 2014 & Financial & Nonfinancial & Total \\
\hline Total firm-year observations & 260 & 685 & 945 \\
Less: & & & $\underline{383}$ \\
Firm-year observations with zero other comprehensive income items & $\underline{94}$ & $\underline{47}$ \\
\hline
\end{tabular}


Total observations with non-zero other comprehensive income items 166 302

Less:

Firm-year observations with no information on share price/dividend $35 \quad 65 \quad 100$

Firm-year observations due to extremely large share price

$\underline{8} \quad \underline{11} \quad \underline{19}$

Firm-year observations 123 226 349

Panel B: Composition by Industry

Firm-year observations

$\% \quad$ Number of firms

$\%$

\section{Financial}

Banks

$\begin{array}{rr}68 & 55.28 \\ 46 & 37.4 \\ \underline{9} & \underline{7.32} \\ \underline{123} & \underline{100}\end{array}$

18

Insurance

37.4

Investment and financial services

7.32

Total

Nonfinancial

\begin{tabular}{lrrrr} 
Agriculture & 9 & 3.98 & 4 & 4.94 \\
Conglomerate & 12 & 5.31 & 5 & 6.17 \\
Construction & 17 & 7.52 & 6 & 7.41 \\
Consumer goods & 63 & 27.88 & 21 & 25.93 \\
Healthcare & 13 & 5.75 & 4 & 4.94 \\
Oil and gas & 19 & 8.41 & 7 & 8.64 \\
Industrial goods & 58 & 25.66 & 19 & 23.46 \\
Services & $\underline{35}$ & $\underline{15.49}$ & $\underline{15}$ & $\underline{18.51}$ \\
Total & 226 & 100 & 81 & 100 \\
\hline
\end{tabular}

Panel C: Combined Sample

Total number of observations

Less firms-year observations without full annual report

Firm-year observations

Note: The sample comprises Nigerian firms with at least one item of other comprehensive income with annual reports between 2010 and 2014.

\section{Research Model}

Corporate governance mechanisms play a broader role in limiting the opportunistic behaviour of managers (Song et al., 2010). A case can be made for reduced agency costs of information asymmetry to the extent that corporate governance mechanisms limit the managerial manipulation of financial reporting, especially other comprehensive income,. Consequently, the strength of corporate governance can enhance the quality of other comprehensive income. Therefore, this section modelled the role of corporate governance mechanism on the investors' pricing of other comprehensive income as:

$$
\begin{aligned}
& S P_{i t}=\beta_{0}+\beta_{1} B V E_{i t}+\beta_{2} N I_{i t}+\beta_{3} O C I_{i t}+\beta_{4} B C G S C O R E_{i t}+\beta_{5} L N I_{i t}+\beta_{6} L O C I_{i t}+ \\
& \beta_{7} O C I_{i t}^{*} B C G S C O R E_{i t}+\beta_{8} L N I_{i t} N I_{i t}+\beta_{9} L O C I_{i t}^{*} O C I_{i t}+\sum_{t=1}^{m} \beta_{10 j} C O N T R O L_{i t}+\varepsilon_{i t}
\end{aligned}
$$


where $\mathbf{S P}$ is the share price four months after the financial year end. BVE is measured as the book value of common equity at the end of the fiscal year deflated by the number of outstanding shares (Kanagaretnam et al., 2009; Mechelli \& Cimini, 2014). NI refers to earnings after tax of a company at the end of the financial year (Dhaliwal et al., 1999; Cahan et al., 2000; Mechelli \& Cimini, 2014). OCI is the sum of items of other comprehensive income (dirty surplus flows), which includes: a) gains and losses on noncurrent assets (REV); b) gains and losses on available-for-sale financial securities (SEC); and c) actuarial gains and losses on defined benefit plans (PEN) as contained in the Nigerian version of IFRS. Other comprehensive income and the components are scaled by the outstanding shares (Wang et al.,2006; Kanagaretnam et al., 2009; Mechelli \& Cimini, 2014). BCGSCORE is a factor score of the corporate governance mechanism using the Principal Components Analysis. The score is obtained by taking the average score from audit committee size, audit committee independence, audit committee expertise, audit committee meetings, auditor's reputation, and no material control weakness. ACIND is the ratio of the independent audit committee members to ACSIZE (Klein, 2002; Habib \& Azim, 2008, Suárez et al., 2013; Woidtke \& Yeh, 2013. ACSIZE is the actual number of audit committee members (Habib \& Azim, 2008; Yasin \& Nelson, 2012; Woidtke \& Yeh, 2013). ACEXP is the proportion of audit committee members possessing professional accounting qualifications relative to audit committee size (Zhang, Zhou, \& Zhou, 2007, Rainsbury et al., 2009; Yasin \& Nelson, 2012). ACMET is the number of meetings conducted during the year (Barua et al., 2010;, Yasin \& Nelson, 2012; Woidtke \& Yeh, 2013). AUDR is coded 1 for companies audited by a Big 4 firm and 0 for companies audited by a non-Big 4 firm (Song et al., 2010; Lee \& Park, 2013). NMICW is given the value of 1 if a firm has not disclosed any material internal control weakness and 0 if otherwise (Doyle et al., 2007; Hammersley et al., 2008; Song et al., 2010; Brown et al., 2014). To test the value relevance differences between high and low governance firms, the data was partitioned into high and low governance firms. This was achieved by computing a RANK variable based on the median value of BCGSORE. To differentiate firms based on best practices, BCGSCORE was split at the median to cluster the sample into two groups. The first group was the strong governance firms (entities with an aggregate score above the median) and the second group was the weak governance firms (entities with an aggregate score below the median). Observations with a score above the median value were coded 1 and 0 for observations with aggregate scores less than the median value (Song et al., 2010). LNI is coded as 1 for negative net income firms and 0 if otherwise. LOCI is coded as 1 for negative OCI firms and 0 if otherwise. The control variables are firm size (FSIZE), foreign investor ownership (FLIB) and industry (IND). FSIZE is the log of market capitalization. FLIB is the percentage of shares held by foreign investors and IND is NSE SIC code.

\section{Results and Analysis}

Table 2 presents the descriptive statistics for regression variables from 2010 to 2014. The mean (median) of SP was \#9.78 (\#2.68) Naira for the period of 2010 to 2014. The pooled fiveyear mean (median) net income was $0.37(0.10)$ billion. The average (median) OCI was 0.03 (0.01), which was far lower than the net income.

For corporate governance variables, the mean proportion of audit committee independence (ACIND) was $0.41 \%$, which was less than the $51 \%$ recommended by CAMA 1990 and SCE 2011. The mean ratio of audit committee expertise (ACEXP) was 0.07 , indicating that not all firms had a chartered accountant sitting on the committee. This result is against the provision of CAMA 1990 and SEC 2011 which stipulate that there should be at least one chartered accountant. 


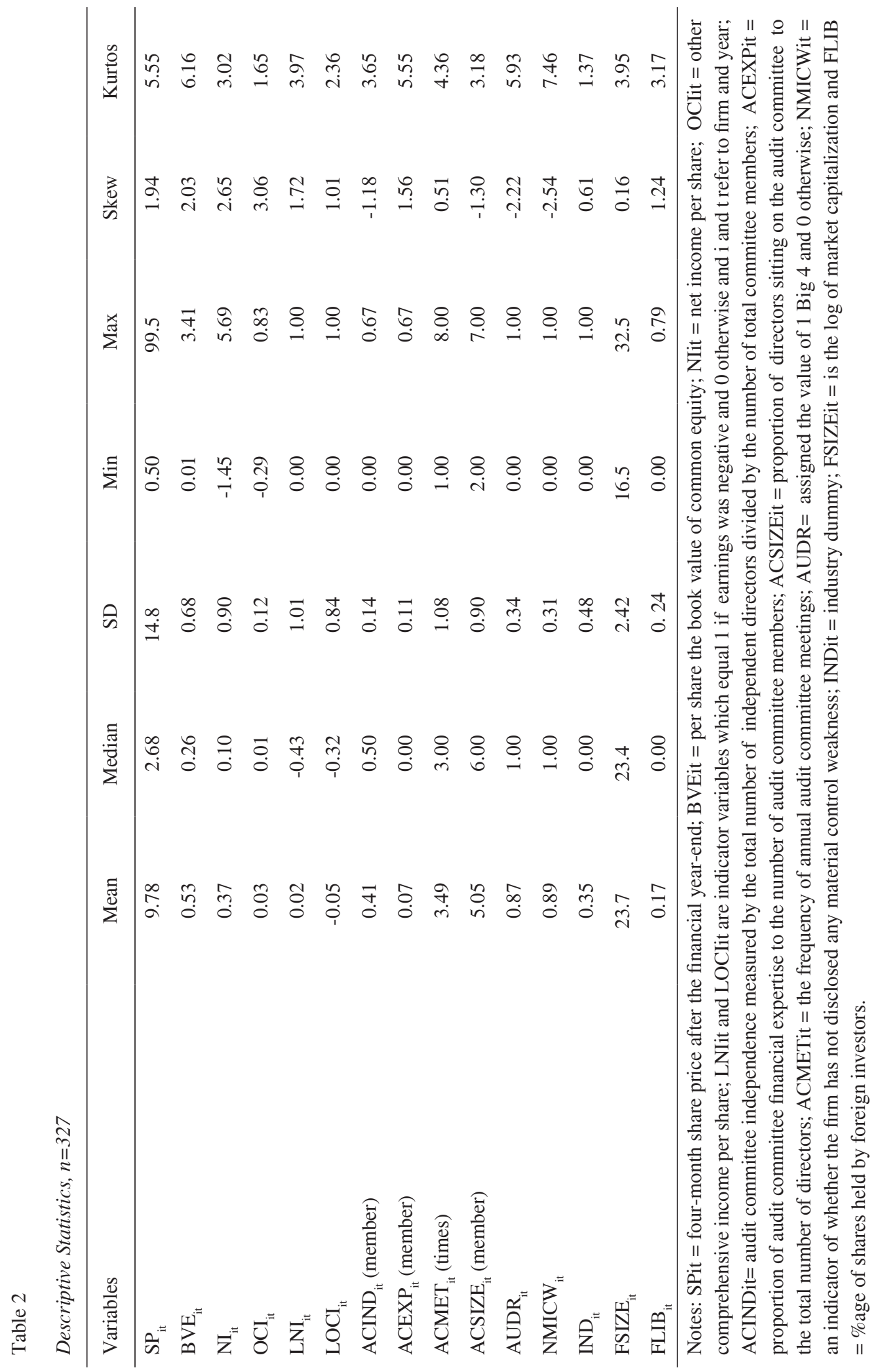




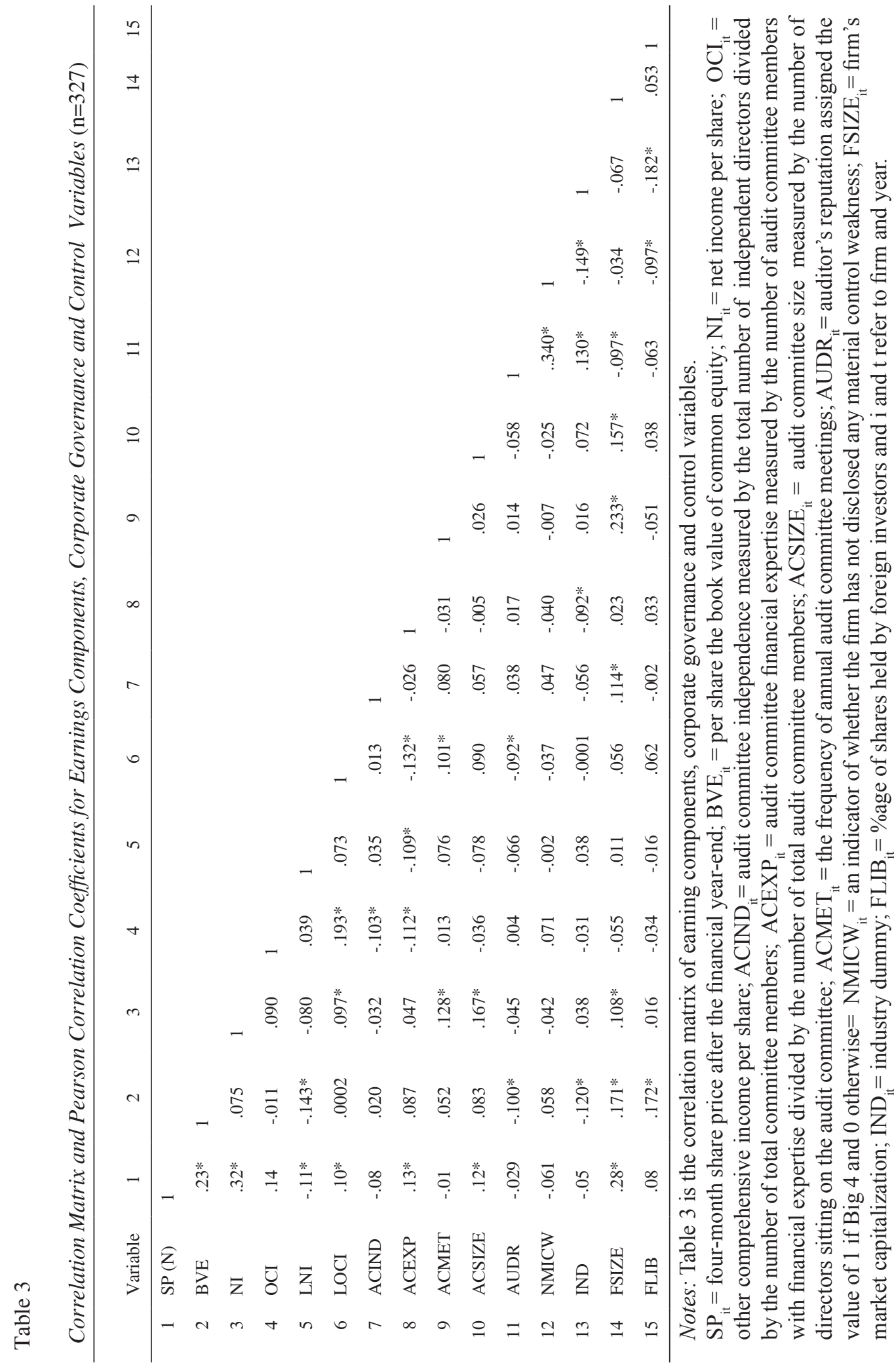


Table 3 delineates the correlation matrix of accounting earnings, corporate governance and control variables. The book value of equity, net income and OCI for the pooled sample were positively correlated with the SP. The corporate governance and control variables included were moderately correlated. Overall, the strength of the relationship between the independent variables were within the acceptable limit. In Table 3 there are no predictor variables with correlation above 0.7 , suggesting the absence of serious multicollinearity problems.

Table 4 presents the results of the overall effect of BCGSCORE on the value relevance of OCI and the valuation differences between strong and weak governance firms. The valuation effect of BCGSCORE on OCI is presented in Panel A. The coefficient on OCI is interpreted as the valuation of OCI for the full sample. The coefficients on the interaction term represents incremental valuations of $\mathrm{OCI}$ given corporate governance mechanism. In Panel A, BVE and NI are positive and statistically significant at $1 \%$. As expected, the coefficient of OCI is positive and significant at $10 \%$. This indicates that aggregate dirty surplus flows is weakly priced, perhaps, because it comprises of several fair value adjustments involving different valuation inputs (Song et al., 2010). It is also noteworthy that the coefficients on the interaction term (OCI*BCGSCORE) is positive and statistically significant at $5 \%$. This result suggests an incremental value relevance of OCI when conditioned for BCGSCORE as Song et al. (2010) and Lee and Park (2013) documented. This suggests that the perceived effectiveness of monitoring mechanisms may motivate investors to place heavy weights on reported accounting earnings.

Panel B of Table 4 shows the result of the sample partitioned for strong and weak corporate governance firms based on the median value of BCGSCORE. The coefficient of OCI without interaction is interpreted as fair value valuation of low governance firms. The coefficient of the interaction term (OCI*RANK) captures the incremental valuation when moving from weak to strong corporate governance firms. The result in Panel B shows that the regression coefficient on the book value of equity and net income are positive and significantly better at $1 \%$. The coefficient of OCI without interaction terms is positive and significant at $10 \%$ as predicted for $\beta_{7}$ in Equation 1. Interestingly, the coefficient of the interaction term is positive and significant at $10 \%$. To determine the impact of strong corporate governance on the valuation of OCI, the coefficients of the non-interaction term (OCI) and that of the interaction term (OCI*BCGRANK) are added. The sum of these coefficients indicates the impact of strong corporate governance on the value relevance of OCI as Song et al. (2010) posited.

Table 4

Regressions Using Governance Rank Covering 2010- 2014 when $n=327$ (Dependent Variable= Share Price)

\begin{tabular}{|c|c|c|c|c|c|c|c|}
\hline \multirow[t]{2}{*}{ Variable } & & \multicolumn{3}{|c|}{$\begin{array}{l}\text { Panel A } \\
\text { Effect of BCGSCORE on OCI }\end{array}$} & \multicolumn{3}{|l|}{$\frac{\text { Panel B }}{\text { Sample }}$} \\
\hline & Sign & Coef & $\begin{array}{l}\text { Std } \\
\text { Error }\end{array}$ & $\mathrm{t}$ & Coef & $\begin{array}{l}\text { Std } \\
\text { Error }\end{array}$ & $\mathrm{t}$ \\
\hline CONS & $+/-$ & -3.49 & 1.30 & $-2.67 * * *$ & -3.99 & 1.32 & $2.54 * * *$ \\
\hline $\mathrm{BVE}_{\mathrm{it}}$ & + & 0.67 & 0.26 & $3.67 * * *$ & 0.64 & 0.22 & $2.92 * * *$ \\
\hline NIit & + & 0.70 & 0.17 & $4.24 * * *$ & 0.73 & 0.17 & $4.26^{* * * *}$ \\
\hline
\end{tabular}




\begin{tabular}{|c|c|c|c|c|c|c|c|}
\hline Variable & & $\frac{\text { Panel A }}{\text { Effect }}$ & CGSC & E on OCI & \multicolumn{3}{|l|}{$\begin{array}{l}\text { Panel B } \\
\text { Sample } \\
\text { partition } \\
\text { for high } \\
\text { and low } \\
\text { firms }\end{array}$} \\
\hline $\mathrm{OCI}_{\mathrm{it}}$ & + & 0.32 & 0.18 & $1.73^{*}$ & 0.32 & 0.19 & $1.74 *$ \\
\hline BCGSCORE $_{\text {it }}$ & $?$ & -0.02 & 0.07 & -0.34 & & & \\
\hline RANK $_{\mathrm{it}}$ & + & - & - & - & -0.01 & 0.21 & -0.04 \\
\hline $\mathrm{LNI}_{\mathrm{it}}$ & + & -0.01 & 0.10 & 0.03 & 0.01 & 0.10 & 0.14 \\
\hline $\mathrm{LOCI}_{\mathrm{it}}$ & - & -0.12 & 0.14 & -0.08 & 0.04 & 0.13 & 0.30 \\
\hline $\mathrm{OCI}^{*} \mathrm{BCGSCORE}_{\mathrm{it}}$ & & 0.16 & 0.07 & $2.15^{* *}$ & - & - & - \\
\hline OCI*RANK $\mathrm{it}_{+}$ & & - & - & - & 0.56 & 0.33 & $1.69^{*}$ \\
\hline $\mathrm{LNI}^{*} \mathrm{NI}_{\mathrm{it}}$ & $?$ & 0.11 & 0.09 & 1.29 & 0.16 & 0.10 & $1.70^{*}$ \\
\hline $\mathrm{LOCI}^{*} \mathrm{OCI}_{\mathrm{it}}$ & + & 0.06 & 0.09 & 0.60 & 0.03 & 0.09 & 0.35 \\
\hline FSIZE $_{i t}$ & + & 0.16 & 0.56 & $3.48^{* * *}$ & 0.16 & 0.06 & $2.85 * * *$ \\
\hline $\mathrm{IND}_{\mathrm{it}}$ & + & 0.00 & 0.00 & 1.46 & 0.00 & 0.00 & 1.39 \\
\hline FLIB $_{\text {it }}$ & + & 0.14 & 0.14 & $2.78^{* * *}$ & 0.14 & 0.04 & $3.45^{* * *}$ \\
\hline F-statistics & & & & $5.77 * * *$ & & & $5.76 * * *$ \\
\hline $\mathrm{R}^{2}$ & & $35.08 \%$ & & & $35.86 \%$ & & \\
\hline
\end{tabular}

Notes: $\mathrm{BVE}_{\mathrm{it}}=$ per share book value of common equity; $\mathrm{NI}_{\mathrm{it}}=$ net income per share; $\mathrm{OCI}_{\mathrm{it}}=$ aggregate other comprehensive income per share; BCGSCORE $_{\mathrm{it}}=$ corporate governance scores; $\mathrm{RANK}_{\mathrm{it}}=$ the median rank of $\mathrm{BCGSCORE}_{\mathrm{it}}$, ranging from 0 to 1 ; $\mathrm{LNI}_{\mathrm{it}}$ and $\mathrm{LOCI}_{\mathrm{it}}$ are indicator variables that equal lif earnings are negative and 0 if otherwise. OCI*BCGSCORE ${ }_{\mathrm{it}}$ and OCI*RANK $\mathrm{it}_{\mathrm{it}}$ are interactions with OCI; $\mathrm{LNI}^{*} \mathrm{NI}_{\mathrm{it}}$ and LOCI* $\mathrm{OCI}_{\mathrm{it}}$ are interaction terms for loss firms and $i$ and $t$ refer to firm and year.

$*, * *$, and $* * *$ denote significance at the $10 \%, 5 \%$, and $1 \%$ levels respectively.

For strong governance firms, valuations of OCI increased to near 1 ( 0.88 sum of 0.32 and 0.56$)$, suggesting an incremental value relevance of OCI given strong corporate governance practices. This finding provides evidence that OCI of strong corporate governance firms was more positively priced than those of the weak governance companies. Thus, $\mathrm{H}_{1}$ is supported.

To test $\mathrm{H}_{2}$, Equation 1 is estimated separately for each element of corporate governance. Table 5 presents the results of the effect of individual elements of corporate governance on the valuation of other comprehensive income. The elements tested are the audit committee independence, audit committee financial expertise, audit committee size, audit committee meetings, auditor's reputation and internal control effectiveness. The results for Model 1 of Table 5 (audit committee independence) and Model 2 of Table 5 (audit committee financial expertise) are not significant indicating that audit committee independence and financial expertise do not influence the valuation of OCI.

Model 3 of Table 5 shows that the coefficient on the interaction between OCI and audit committee size (OCI*ACSIZE) was positive and significant. This implies that the composition of an audit committee in terms of number positively influenced the value relevance of other comprehensive income. This result is in the same direction of Yang and Krishnan (2005) who documented a positive influence of a large audit committee on the financial reporting quality. 
Table 5

The Effect of Ind=ividual Element of Corporate Governance on the Value Relevance of Other Comprehensive Income $(n=327)$

\begin{tabular}{|c|c|c|c|c|c|c|}
\hline & Model 1 & Model 2 & Model 3 & Model 4 & Model 5 & Model 6 \\
\hline & $\begin{array}{l}\text { Audit committee } \\
\text { independence }\end{array}$ & $\begin{array}{l}\text { Audit } \\
\text { committee } \\
\text { financial } \\
\text { expertise }\end{array}$ & $\begin{array}{l}\text { Audit } \\
\text { committee } \\
\text { size }\end{array}$ & $\begin{array}{l}\text { Audit } \\
\text { committee } \\
\text { meeting }\end{array}$ & $\begin{array}{l}\text { Auditor's } \\
\text { reputation }\end{array}$ & $\begin{array}{l}\text { Internal } \\
\text { control } \\
\text { effectiveness }\end{array}$ \\
\hline & (ACIND) & (ACEXP) & (ACSIZE) & (ACMET) & (AUDR) & (NMICW) \\
\hline & $\begin{array}{l}\text { Coef. } \\
\text { (t-value) }\end{array}$ & $\begin{array}{l}\text { Coef. } \\
\text { (t-value) }\end{array}$ & $\begin{array}{l}\text { Coef. } \\
\text { (t-value) }\end{array}$ & $\begin{array}{l}\text { Coef. } \\
\text { (t-value) }\end{array}$ & $\begin{array}{l}\text { Coef. } \\
\text { (t-value) }\end{array}$ & $\begin{array}{l}\text { Coef. } \\
\text { (t-value) }\end{array}$ \\
\hline CONS & $\begin{array}{l}-3.56 \\
(-3.45)^{* * * *}\end{array}$ & $\begin{array}{l}-3.47 \\
(-3.38) * * *\end{array}$ & $\begin{array}{l}-3.92 \\
(-3.48)^{* * * *}\end{array}$ & $\begin{array}{l}-3.81 \\
(-3.67) * * *\end{array}$ & $\begin{array}{l}-3.46 \\
(1.07)^{* * * *}\end{array}$ & $\begin{array}{l}-3.47 \\
(-3.18) * * *\end{array}$ \\
\hline $\mathrm{BVE}_{\mathrm{it}}$ & $\begin{array}{l}0.67 \\
(3.77)^{* * * *}\end{array}$ & $\begin{array}{l}0.70 \\
(4.21)^{* * * *}\end{array}$ & $\begin{array}{l}0.65 \\
(3.90)^{* * * *}\end{array}$ & $\begin{array}{l}0.69 \\
(4.16)^{* * * *}\end{array}$ & $\begin{array}{l}0.60 \\
(3.57)^{* * * *}\end{array}$ & $\begin{array}{l}0.63 \\
(3.78)^{* * * *}\end{array}$ \\
\hline $\mathrm{NI}_{\mathrm{it}}$ & $\begin{array}{l}0.70 \\
(7.05)^{* * * *}\end{array}$ & $\begin{array}{l}0.70 \\
(7.12)^{* * * *}\end{array}$ & $\begin{array}{l}0.71 \\
(7.15)^{* * * *}\end{array}$ & $\begin{array}{l}0.72 \\
(7.19)^{* * *}\end{array}$ & $\begin{array}{l}0.67 \\
(6.78)^{* * * *}\end{array}$ & $\begin{array}{l}0.72 \\
(6.69) * * *\end{array}$ \\
\hline $\mathrm{OCI}_{\mathrm{it}}$ & $\begin{array}{l}0.32 \\
(4.48)^{* * * *}\end{array}$ & $\begin{array}{l}0.33 \\
(4.46) * * *\end{array}$ & $\begin{array}{l}0.32 \\
(4.57)^{* * * *}\end{array}$ & $\begin{array}{l}0.30 \\
(4.26) * * *\end{array}$ & $\begin{array}{l}0.24 \\
(3.15)^{* * * *}\end{array}$ & $\begin{array}{l}0.33 \\
(7.29) * * *\end{array}$ \\
\hline GOVELEM $_{\mathrm{it}}$ & $\begin{array}{c}0.07 \\
(0.24)\end{array}$ & $\begin{array}{l}-0.73 \\
(-0.84)\end{array}$ & $\begin{array}{c}0.03 \\
(0.27)\end{array}$ & $\begin{array}{c}0.07 \\
(0.78)\end{array}$ & $\begin{array}{c}0.01 \\
(0.05)\end{array}$ & $\begin{array}{l}-0.40 \\
(-1.26)\end{array}$ \\
\hline${\text { OCI } * \text { GEVELEM }_{\mathrm{it}}}$ & $\begin{array}{c}0.07 \\
(1.29)\end{array}$ & $\begin{array}{c}0.26 \\
(0.26)\end{array}$ & $\begin{array}{l}0.20 \\
(2.09)^{* *}\end{array}$ & $\begin{array}{l}0.25 \\
(2.04)^{* *}\end{array}$ & $\begin{array}{l}0.29 \\
(2.65)^{* * *}\end{array}$ & $\begin{array}{l}2.15 \\
(2.45)^{* *}\end{array}$ \\
\hline $\mathrm{LNI}_{\mathrm{it}}$ & $\begin{array}{c}0.01 \\
(0.07)\end{array}$ & $\begin{array}{l}-0.01 \\
(-1.61)\end{array}$ & $\begin{array}{c}0.02 \\
(0.17)\end{array}$ & $\begin{array}{c}0.02 \\
(0.22)\end{array}$ & $\begin{array}{l}-0.02 \\
(-0.19)\end{array}$ & $\begin{array}{c}0.01 \\
(0.08)\end{array}$ \\
\hline $\mathrm{LOCI}_{\mathrm{it}}$ & $\begin{array}{c}0.02 \\
(0.16)\end{array}$ & $\begin{array}{c}0.03 \\
(0.10)\end{array}$ & $\begin{array}{c}0.04 \\
(0.31)\end{array}$ & $\begin{array}{c}0.01 \\
(0.09)\end{array}$ & $\begin{array}{c}0.02 \\
(0.13)\end{array}$ & $\begin{array}{c}0.05 \\
(0.39)\end{array}$ \\
\hline $\mathrm{LNI}^{*} \mathrm{NI}_{\mathrm{it}}$ & $\begin{array}{c}0.12 \\
(0.91)\end{array}$ & $\begin{array}{l}0.05 \\
(2.22)^{* *}\end{array}$ & $\begin{array}{c}0.14 \\
(1.21)\end{array}$ & $\begin{array}{l}-0.11 \\
(0.84)\end{array}$ & $\begin{array}{c}0.14 \\
(1.13)\end{array}$ & $\begin{array}{c}0.17 \\
(1.29)\end{array}$ \\
\hline $\mathrm{LOCI}^{*} \mathrm{OCI}_{\mathrm{it}}$ & $\begin{array}{c}0.05 \\
(0.61)\end{array}$ & $\begin{array}{c}0.03 \\
(0.39)\end{array}$ & $\begin{array}{c}0.04 \\
(0.52)\end{array}$ & $\begin{array}{c}0.05 \\
(0.62)\end{array}$ & $\begin{array}{c}0.03 \\
(0.29)\end{array}$ & $\begin{array}{c}0.03 \\
(0.39)\end{array}$ \\
\hline FSIZE $_{i t}$ & $\begin{array}{l}0.14 \\
(3.98)^{* * * *}\end{array}$ & $\begin{array}{l}0.15 \\
(3.57)^{* * * *}\end{array}$ & $\begin{array}{l}0.16 \\
(3.67)^{* * *}\end{array}$ & $\begin{array}{l}0.15 \\
(3.42)^{* * * *}\end{array}$ & $\begin{array}{l}0.13 \\
(3.59)^{* * * *}\end{array}$ & $\begin{array}{l}0.16 \\
(3.78)^{* * *}\end{array}$ \\
\hline $\mathrm{IND}_{\mathrm{it}}$ & $\begin{array}{c}0.00 \\
(1.11)\end{array}$ & $\begin{array}{c}0.00 \\
(1.09)\end{array}$ & $\begin{array}{l}-0.00 \\
(1.34)\end{array}$ & $\begin{array}{c}0.00 \\
(1.36)\end{array}$ & $\begin{array}{c}0.00 \\
(1.02)\end{array}$ & $\begin{array}{c}0.00 \\
(1.17)\end{array}$ \\
\hline FLIB $_{i t}$ & $\begin{array}{l}0.14 \\
(3.61)^{* * * *}\end{array}$ & $\begin{array}{l}0.13 \\
(3.74)^{* * * *}\end{array}$ & $\begin{array}{l}0.14 \\
(3.97)^{* * * *}\end{array}$ & $\begin{array}{l}0.14 \\
(3.91)^{* * * *}\end{array}$ & $\begin{array}{l}0.10 \\
(3.87)^{* * * *}\end{array}$ & $\begin{array}{c}0.14 \\
(-3.98)^{* * *}\end{array}$ \\
\hline F-statistics & $13.87 * * *$ & $14.27 * * *$ & $14.11 * * *$ & $14.12 * * *$ & $14.44 * * *$ & $11.44 * * *$ \\
\hline Observations & 327 & 327 & 327 & 327 & 327 & 327 \\
\hline $\mathrm{R}_{2}$ & $34.65 \%$ & $35.29 \%$ & $35.04 \%$ & $25.05 \%$ & $35.56 \%$ & $35.57 \%$ \\
\hline
\end{tabular}

Notes: $\mathrm{BVE}_{\mathrm{it}}=$ per share book value of common equity; $\mathrm{NI}_{\mathrm{it}}=$ net income per share; $\mathrm{OCI}_{\mathrm{it}}=$ other comprehensive income per share; GOVELEMit $=$ the score of individual governance variable; $\mathrm{OCI}^{*} \mathrm{GOVELEM}_{\mathrm{it}}=$ the interaction between OCI and audit committee independence (ACIND); audit committee financial expertise (ACEXP) and audit committee size (ACSIZE) measured by the number of directors sitting on the audit committee, frequency of annual audit committee meetings (ACMET); auditor's reputation (AUDR) assigned the value of 1 if Big_4 and 0 if otherwise and an indicator of whether the firm has not disclosed any material control weakness (NMICW). $\mathrm{LNI}_{\mathrm{it}}$ and $\mathrm{LOCI}_{\mathrm{it}}$ are indicator variables which equal 1 if earnings are negative and 0 if otherwise; $\mathrm{LNI}^{*} \mathrm{NI}_{\mathrm{it}}$ and LOCI $* \mathrm{OCI}_{\mathrm{it}}$ are interaction terms for loss firms and $i$ and $t$ refer to firm and year.

$*, * *$, and $* * *$ denote significance at the $10 \%, 5 \%$, and $1 \%$ levels respectively 
For Model 4 of Table 5, an audit committee that meets frequently to review the internal accounting controls and audit process tends to be more effective and focused on the financial reporting quality and hence the quality of accounting information (Barua et al., 2010; Woidtke \& Yeh, 2013). In this study, the coefficient on the interaction between audit committee meeting and aggregate other comprehensive income (OCI*ACMET) was positive and statistically significant at $5 \%$. This implies that the frequency of meetings has an incremental effect on the value relevance of other comprehensive income. As documented in previous studies, the frequency of audit committee meetings is important in keeping the members abreast of the relevant financial reporting and current audit issues (Yasin \& Nelson, 2012). To further highlight the importance of the audit committee meetings, regulators, among others, expressed diligence of the audit committee as a function of the number of audit committee meetings because it is critical in fulfilling their audit committee oversight function (Yasin \& Nelson, 2012).

Another element of corporate governance included in the BCGSCORE is the external auditor type. Model 5 of Table 5 presents the result of the interaction between external auditor type and OCI. The coefficient of the interaction term (OCI*AUDR) was positive and statistically significant at $1 \%$. This finding concurs with Song et al. (2010), Lee and Lee (2011), Francis and Michas (2013) and Lee and Park (2013) who investigated the role of an auditor's reputation in reducing the subjectivity of fair value measurement. Because Big 4 audit firms possess vast professional and technical skills and have reputations at stake, they have stronger incentives for ensuring that financial statements reflect the true and fair view to maintain public trust on reporting entities. Thus, an external auditor's involvement in the operation of Nigerian capital market could play a broader role in limiting the opportunistic behavior of the managers from manipulating accounting amounts and consequently reduce agency cost and increases the reliability of earnings.

Further, the result presented in Model 6 of Table 5 suggests positive and significant interaction
$(\mathrm{OCI} * \mathrm{NMICW})$ between no material internal control weakness and OCI. This finding is in line with Brown et al. (2014). Information about no material internal control weakness signals the soundness of the sample firms internal control system, which is typical in detecting and preventing aggressive financial reporting (Brown et al., 2014). Effective internal control system could curtail management's forecasts and estimates so that they do not lead to misrepresentation of the financial statement (Gordon et al., 2006). As documented in previous studies, this study affirmed that highquality of internal control system is negatively associated with intentional manipulation and estimation errors, suggesting an incremental value relevance of OCI when conditioned for no material internal control weakness.

Overall, this finding provides strong evidence on the greater impact of corporate governance mechanism on the valuation of OCI. Because fair value inputs are less verifiable by investors and prone to greater management estimation errors as well as intentional manipulation, market participants may perceive OCI of firms with strong corporate governance to be more value relevant. Thus, the individual items continue to support $\mathrm{H}_{2}$ on the impact of corporate governance mechanisms on the value relevance of OCI in the NSE market.

\section{Conclusion}

This study investigated whether investors placed different weight on other comprehensive income based on the strength of the corporate governance mechanism. Based on the data from firms listed on the NSE market, the test of the impact of corporate governance mechanism on investors' pricing of other comprehensive income was consistent with our prediction. We found that the value relevance of other comprehensive income varied with the strength of the firm's corporate governance. This implies that investors place different weight on other comprehensive income based on the strength of the corporate governance mechanism. For firms with weak governance mechanisms, other comprehensive income 
is value relevant, but was more significantly priced for strong governance firms. The results of the six individual governance measures also continue to support the greater importance of governance practice on the valuation of other comprehensive income. Given that other comprehensive income represents an accounting earnings generated from various dirty surplus flows, information asymmetry is expected to be high for such earnings. The observed increase in the explanatory power of other comprehensive income when interacting with the corporate governance factor score is supportive of the argument that effective corporate governance curtails information asymmetry through reduced management estimation errors or induced measurement biases. Therefore, to the extent that corporate governance mitigates reliability concerns associated with fair value earnings, agency cost will be minimised and investors are more likely to view other comprehensive income as more value relevant.

\section{References}

Abdullah, S. N., \& Ku-Ismail, K. N. I. (1999). Audit committee effectiveness among Malaysian listed companies. Malaysian Management Journal, 3(2), 1-13.

Agrawal, A., \& Chadha, S. (2005). Corporate governance and accounting scandals. Journal of Law and Economics, 48, 371406.

Barua, A., Rama, D. V., \& Sharma, V. (2010). Audit committee characteristics and investment in internal auditing. Journal of Accounting and Public Policy, 29(5), 503-513.

Barth, M. E., \& Clinch, G. (1998). Revalued financial, tangible, and intangible assets: Associations with share prices and nonmarket-based value estimates. Journal of Accounting Research, 36(3), 199-233.

Bartov, E., Mohanram, P., \& Nissim, D. (2007). Managerial discretion and the economic determinations of the disclosed volatility parameter for valuing ESOs. Review of Accounting Studies, 12(1), 155-179.

Brown. N. C., Pott. C., \& Wömpener, A. (2014). The effect of internal control and risk management regulation on earnings quality: Evidence from Germany. Journal of Accounting and Public Policy, 33,1-31.

Cahan, S. F., Courtenay, S. M., Gronewoller, P. L., \& Upton, D. R. (2000). Value relevance of mandated comprehensive income disclosures. Journal of Business Finance \& Accounting, 27(9), 1273-1302.

Chambers, D., Linsmeier, T. J., Shakespeare, C., \& Sougiannis, T. (2007). An evaluation of SFAS No. 130 comprehensive income disclosures. Review of Accounting Studies, 12, 557-593.

Chen, C. J. P., \& Jaggi, B. (2000). Association between independent non-executive directors, family control and financial disclosures in Hong Kong. Journal of Accounting and Public Policy, 19, 85310.

Christensen, B., Glover, S., \& Wood, D. A. (2012). Extreme estimation uncertainty in fair value estimates: Implications for audit assurance, Auditing: A Journal of Practice \& Theory, 31(1), 127-146.

Davidson, W. N., Xie, B., \& Xu, W. (2004). Market reaction to voluntary announcements of audit committee appointments: The effect of financial expertise. Journal of Accounting and Public Policy, 23(4), 279-293.

DeFond, M. L. (2010). How should the auditors be audited? Comparing the PCAOB inspections with the AICPA peer reviews. Journal of Accounting and Economics, 49(1-2), 104-108.

Dhaliwal, D., Subramanyam, K. R., \& Trezevant, R. (1999). Is comprehensive income superior to net income as a measure of firm performance? Journal of Accounting and Economics, 26, 43-67.

Doyle, J. T., Ge, W., \& McVay, S. (2007a). Accruals quality and internal control over financial reporting. The Accounting Review, 82(5) 1141-1170.

Firescu, V. (2015). Comprehensive income, a new dimension in performance measurement and reporting. Procedia Economics and Finance, 20, 218-223.

Francis, J. R., \& Michas, P. N. (2013). The contagion effect of low-quality audits. 
The Accounting Review, 88(2), 521-552. doi:10.2308/accr-50322.

Francis, J., \& Wang, D. (2008). The joint effect of investor protection and Big 4 audits on earnings quality around the world. Contemporary Accounting Research, 25(1), 157-191.

Gordon, L., Loeb, M., Lucyshyn, W., \& Sohail, T. (2006). The impact of the SarbanesOxley Act on the corporate disclosures of information securities activities. Journal of Accounting and Public Policy, 25, 503-530.

Habib, A., \& Azim, I. (2008). Corporate governance and the value-relevance of accounting information: Evidence from Australia. Accounting Research Journal, 21(2), 167-194.

Hirst, D. E., \& Hopkins, P. E. (1998). Comprehensive income reporting and analysts valuation judgments. Journal of Accounting Research, 36, 47-75.

Hammersley, J. S., Myers, L. A., \& Shakespeare, C. (2008). Market reactions to the disclosure of internal control weaknesses and to the characteristics of those weaknesses under Section 302 of the Sarbanes-Oxley Act of 2002. Review of Accounting Studies , 13(1), 141-165.

Ismail, K. N. I. K., \& Chandler, R. (2005), The reliability of quarterly financial reports of companies in Malaysia. IIUM Journal of Accounting Economics and Management, 13(2), 167-188.

Jones, D. A., \& Smith, K. J., (2011). Comparing the value relevance, predictive value, and persistence of other comprehensive income and special items. Accounting Review, 86, 2047-2073.

Kanagaretnam, K., Mathieu, R., \& Shehata, M., (2009). Usefulness of comprehensive income reporting in Canada. Journal Accounting Public Policy, 28, 349-365.

Kim, Y., \& Park, M. S. (2008). Market uncertainty and disclosure of internal control deficiencies under the SarbanesOxley Act. Journal of Accounting and Public Policy, 28(5), 419-445.

Klein, A. (2002). Audit committee, board of director characteristics and earnings management. Journal of Accounting and Economics, 33, 375-400.

Lee, C., \& Park, M. S. (2013). Subjectivity in fair-value estimates, audit quality, and informativeness of other comprehensive income. Advances in Accounting, incorporating Advances in International Accounting, 29(2), 218-231. doi:10.1016 /j.adiac.2013.05.003.

Lopes, A. B., \& Walker, M. (2012). Asset revaluations, future firm performance and firm-level corporate governance arrangements: New evidence from Brazil. British Accounting Review, 44(2), 53-67.

Maines, L. A., \& McDaniel, L. S. (2000) Effects of comprehensive-income characteristics on nonprofessional investors' judgments: The role of financial-statement presentation format. The Accounting Review, 75(2), 179207.

Maines, L. A., \& Wahlen, J. M. (2006). The nature of accounting information reliability: Inferences from archival and experimental research. Accounting Horizons, 20(4), 399-425.

Mechelli, A., \& Cimini, R. (2014). Is comprehensive income value relevant and does location matter? A European study. Accounting in Europe, 11, 59-87.

Naiker, V., \& Sharma, D. S. (2009). Former audit partners on the audit committee and internal control deficiencies. The Accounting Review, 84(2), 559-587.

Rainsbury, E. A., Bradbury, M., \& Cahan, S. F. (2009). The impact of audit committee quality on financial reporting quality and audit fees. Journal of Contemporary Accounting \& Economics, 5(1), 20-33.

Rezaee, Z. (2004). Corporate governance role. Research in Accounting Regulation, 17, 107149. doi:10.1016/S1052-0457(04),170069.

Song. C. J., Thomas. W. B., \& Yi. H. (2010). Value relevance of FAS No. 157 fair value hierarchy information and the impact of corporate governance mechanisms. The Accounting Review, 85(4), 1375-1410.

Suárez, J. D. A., García, E. C., Méndez, C. F., \& Gutiérrez, C. R. (2013). The 
effectiveness of the audit committee in Spain: Implications of its existence on the auditor's opinion. SERIES, 4, 333352.

Wang, Y., Buijink, W., \& Eken, R. (2006). The value relevance of dirty surplus accounting flows in the Netherlands. The International Journal of Accounting, 41, 387-405.

Woidtke, T., \& Yeh, Y. H. (2013). The role of the audit committee and the informativeness of accounting earnings in East. Asia Pacific-Basin Finance Journal, 23, 1-24.

Xie, B., Davidson III, W. N., \& DaDalt, P.J. (2003). Earnings management and corporate governance: The role of the board and the audit committee. Journal of Corporate Finance, 9, 295-316.

Yang, J., \& Krishnan, J. (2005). Audit committees and quarterly earnings management. International Journal of Auditing, 9, 201-219.

Yasin, F. M., \& Nelson, S. P. (2012). Audit committee and internal audit: Implication on audit quality. International Journal of Economics, Management and Accounting, 20(2),187-218.

Zhang, Y., Zhou, J., \& Zhou, N. (2007). Audit committee quality, auditor independence and internal control weaknesses. Journal of Accounting and Public Policy, 26, 300-332. 